\title{
新型インフルエンザの発生動向 〜医療従事者向け疫学情報〜
}

\section{Ver. 3}

厚生労働省新型インフルエンザ対策推進本部

わが国における新型インフルエンザ (A/H1N1) の流行状況については、平成 21 年 5 月に小 規模な地域的流行を認めたのち、約 3 カ月の小康状態を経て、8 月中旬より半年以上かけて 流行しました。現在は再び小康状態にあると考えられますが、未感染の国民が多く存在する こと、過去の新型インフルエンザの大流行の経験や、今回、イギリスやアメリカでは既に流 行の第二波を経験していること等を踏まえると、今後、来冬までの間には再流行が生じる可 能性があります。医療機関や自治体の担当者の方々は、今後の患者発生動向に注視しつつ、 これまでの経験を踏まえた医療提供体制や感染防止対策を推進していただければと思いま す。そこで、今後の備えにおける参考資料としていただけるように、これまでの発生動向等 について、医療機関や各自治体の協力によるサーベイランス情報をもとに整理いたしまし た。ただし、過去の新型インフルエンザの経験からも、次の流行ではウイルスの特性が変化 する可能性があります。本報告はあくまで現時点の知見をまとめたものですので、今後も最 新の情報に注意しつづけていただきますよう、お願いいたします。

\section{ポイント}

○ わが国における新型インフルエンザの流行は、昨年の 5 月に小規模な地域的流行を認め たのち、約 3 カ月の小康状態を経て 8 月末より急速に拡大した。流行のピークは 11 月 であったと考えられるが、定点あたり受診者数が 1 を上回った期間は実に 29 週間にお よんだ。

○ 3 月下旬までに国民の 6 人に 1 人 がインフルエンザで医療機関を受診したと推定され、 受診者の 1200 人に 1 人が入院し、入院患者の 11 人に 1 人が重症化し、受診者の 10 万 人に 1 人が死亡したものと推計される。

○ 入院した患者のうち、基礎疾患を有する方が重症化しやすく、とくに 20 歳以上において 基礎疾患を有する方の重症化傾向が強いと考えられる。

○死亡例については、発症から入院までの期間は平均 2.4 日と短い。発症から死亡までの 日数は平均 9.5 日であったが、年齢階級で差があり、小児の方が経過が早い傾向がある。

○ 今後の流行予測することは困難である。しかし、新たな流行の波が発生する可能性はあ るものと考え、対策を継続する必要がある。 


\section{、新型インフルエンザの流行状況}

わが国における新型インフルエンザの流行状況 については、図 1 に示すように、定点あたり受診 者数の推移により確認することができます。それ によると、昨年の 5 月に小規模な地域的流行を認 めたのち、約 3 カ月の小康状態を経て 8 月末より 急速に拡大しています。流行のピークは 11 月で あったと考えられますが、定点あたり受診者数が 1 を上回った期間は実に 29 週間におよびました。

また、重症化の状況については、図 2 に示すよ うに、サーベイランス情報を重㸚わせることで 確認することができます。

まず、感染症発生動向調査によると、平成 21 年 7 月 27 日から平成 22 年 3 月 23 日までの新型イン フルエンザによる受診者数は約 2061 万人と推計 されます。ただし、これはインフルエンザ様症状 を呈し、かつ医療機関を受診した患者数であって、 医療機関を受診せずに自宅療養をしている方や不 顕性感染の方を含んでいません。

次に、入院患者については、入院サーベイラン スにより、7月 28 日から 3 月 23 日までに全国の 医療機関から 17583 人の報告をいただいています。 さらに、このうち 1641 人が入院中に急性脳症と診 断されるか、人工呼吸器を使用もしくは I C Uに 入室しています。また、自治体からの報告による と 3 月 23 日の時点で新型インフルエンザ感染と診 断され死亡した方が 198 人となっています。

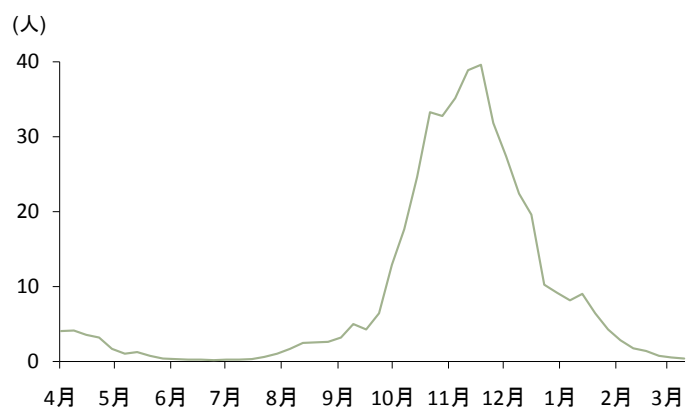

図1定点あたり受診者数の推移 (平成21年度)

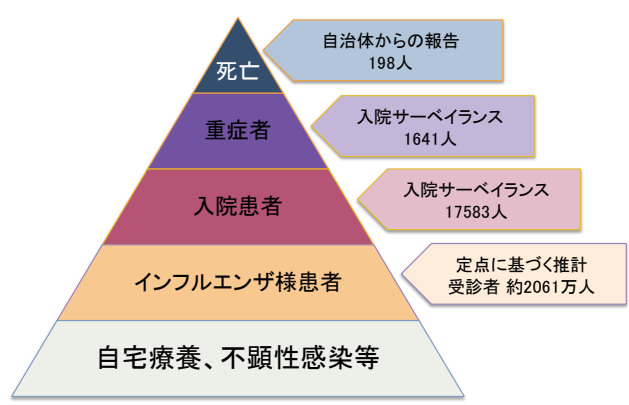

図2 新型インフルエンザの重症度 平成22年3月23日現在/厚生労做省

これらの情報から、3 月下旬までに国民の 6 人に 1 人がインフルエンザで医療機関を受診し、受診者 の 1200 人に 1 人が入院し、入院患者の 11 人に 1 人 が重症化し、受診者の 10 万人に 1 人が死亡したも のと推定されます。

\section{入入院患者及び重症患者の分析}

図 3 に 7 月 28 日から 3 月 23 日までの入院サー ベイランスの報告による入院患者における疾患群 別の基礎疾患保有率を示します。全入院のうち基 礎疾患を有さない方が約 $62.8 \%$ を占めており、感 染した場合に入院を要する状態になる方において、 基礎疾患を有しない方も少なくないことが分かり ます。

図 4 では、図 3 に示したものを小児（15 歳未 満）と 15 歳以上に分けたものです。15 歳以上に おいては、基礎疾患を有しない者が入院した方の

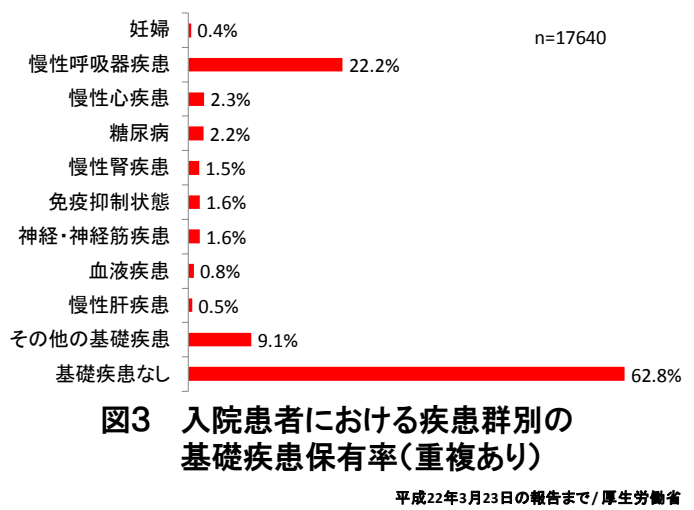




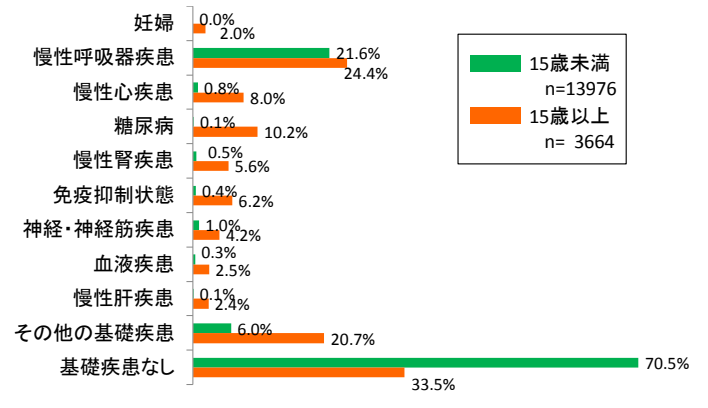

図4 年齢階級別入院患者における疾患群別の 基礎疾患保有率(重複あり)

平成22年3月23日の報告まで/厚生労蕉省

3 割程度にとどまっており、慢性呼吸器疾患や糖 尿病、慢性心疾患、慢性腎疾患など、重症化しや すいとされる基礎疾患を有する方が多く入院して いることが分かります。

図 5 は重症患者における疾患群別の基礎疾患保 有率を示しています。ここで言う重症とは、急性 脳症と診断されるか、入院中に人工呼吸器を使用 もしくは I C Uに入室した事例と定義しています。 図 3 と比較すると、入院している患者のうち、基 礎疾患を有する方が重症化しやすいことが示唆さ れます。また、図6は、図 5 に示したものを小児 （15 歳未満）と 15 歳以上に分けて基礎疾患を分 類していますが、図 4 と同様、15 歳以上において 基礎疾患を有する方の重症化傾向が示唆されます。

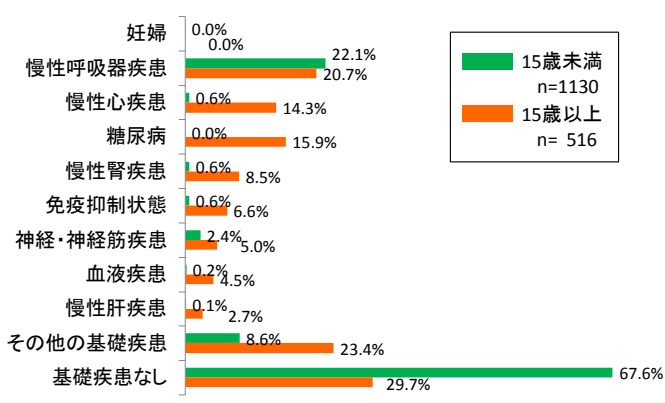

図6 年齢階級別重症患者における疾患群別の 基礎疾患保有率(重複あり)

\section{४死亡事例の分析}

3 月 23 日までに自治体を通じて厚生労働省に報 告された死亡事例 198 例について、年齢分布や臨 床経過、基礎疾患などの情報を示します。

全死亡事例の年齢分布を図 7 に示します。死亡 者数は 40 歳以上の中・高齢者と 10 歳未満に多く、 10 代の死亡例は少数でした。

次に入院患者数に対する死亡数を年齢階級別に 図 8 に示します。小児では、5 歳から 14 歳までの 入院患者あたりの死亡数は少なく、一方で 20 歳以 上では入院患者あたりの死亡数は多くみられまし た。

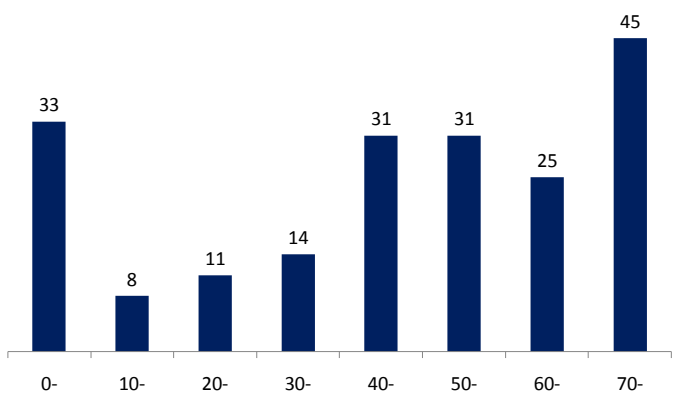

図7 年齢階級別にみた死亡者数 


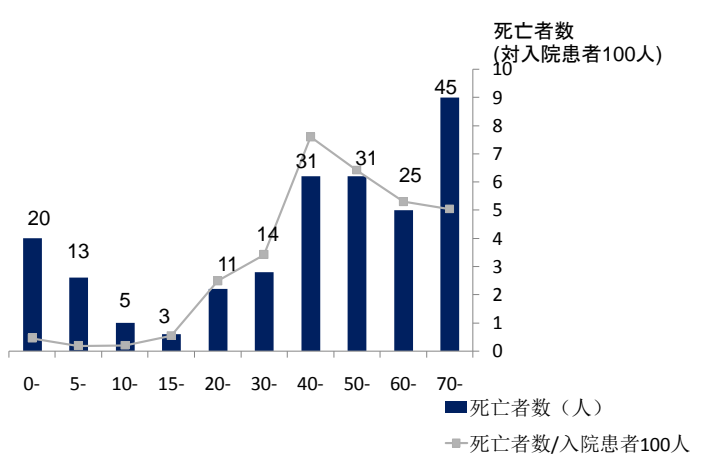

図8 入院患者 100 人当たりの年齢階級別死亡数

平成22年3月23日の報告まで/厚生労鮒省

\section{発症から死亡までの経過}

死亡例全例における発症から死亡までの日数を みると、平均 9.5 日（中央值 5.0 日）と早い経過 で亡くなっており、入院してから死亡するまでの 期間も平均 7.4 日（中央值 3.0 日）と短く、発症 後に短期間で入院し、早期に亡くなっているとい う臨床経過が分かります。ただし、発症日につい ては主治医からの報告に基づいており、基準は統 一されていないことにご注意ください。

15 歳未満の小児 $(\mathrm{N}=38)$ 、 15 歳以上 65 歳未満の 者 $(\mathrm{N}=104)$ と 65 歳以上の高齢者 $(\mathrm{N}=56)$ に年齢で三 分してみると、15 歳未満の小児死亡例では、発症 から入院までの平均日数は 1.0 日 (中央值 1.0 日)、 発症から死亡までの平均日数は 6.6 日 (中央值 2.0 日）であり、他の年齢層の死亡例よりも急速な臨 床経過をとっていました。また、15 歳以上 65 歳 未満の死亡例については、発症から入院までの平 均日数は 3.1 日（中央值 2.0 日）、発症から死亡ま での平均日数は 9.7 日（中央值 5.0 日）と早い経 過でした。6 歳以上の高齢者死亡例では、発症か ら死亡までの平均日数は 11.2 日（中央值 7.0 日） と若年者と比較して長い経過を認めました。

詳細なデータが利用可能であった死亡例 (N=198)のうち 85.3\%（163/198）に対して抗ウイ ルス薬が投与されていました。投与開始は発症後 平均 2.2 日（中央值 1.0 日）でした。また、治療 経過中に体外式膜型人工肺（Extracorporea1
Membrane Oxygenation：ECMO）を使用したと報告 された死亡例は 14 例であり、そのうち 2 例が 15 歳未満でした。

\section{•直接死因と重症化リスク}

主治医の報告に基づく死因を、年齢区分別に図 9〜1 1 に示します。

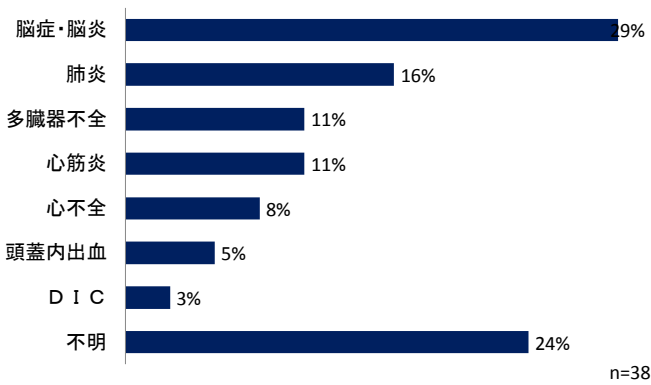

図9 小児(15歳未満)における死因(重複あり)

平成22年3月23日の報告まで/匽生労仳省

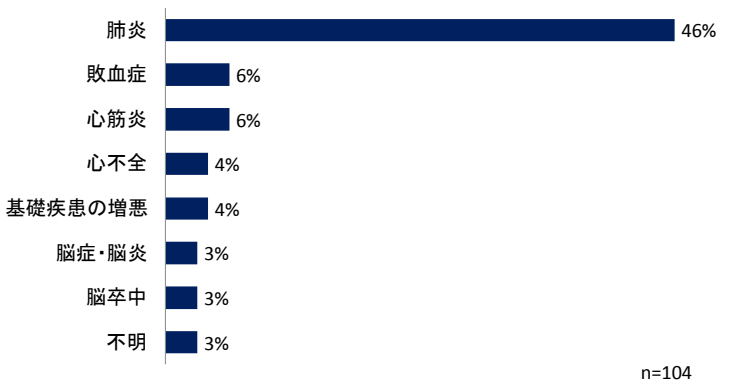

図10 15歳以上65歳未満における死因(重複あり)

平成22年3月23日の報告まで/厚生労倠省

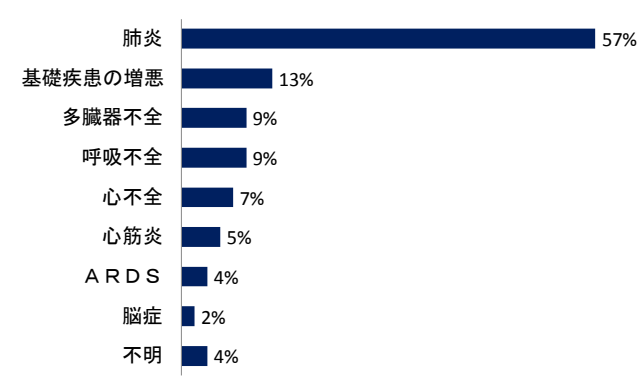

図11 高齢者(65歳以上)における死因(重複あり) 


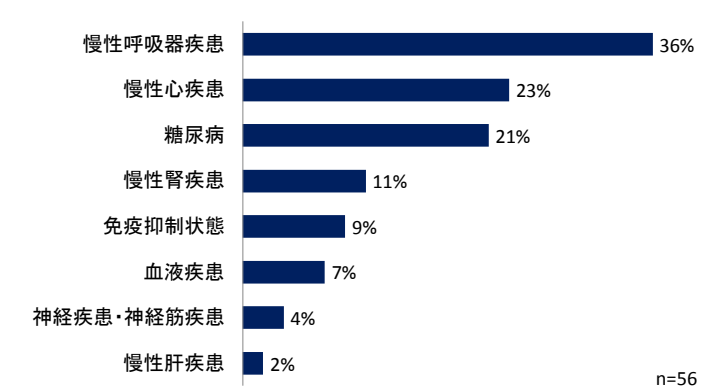

図12 高齢者(65歳以上)死亡例の基礎疾患(重複あり)

平成22年3月23日の報告まで/厚生労勸省

小児 (15 歳未満) では、脳症・脳炎が全体の $29 \%$ $(11 / 38)$ とと最も多く、肺炎 $16 \%(6 / 38)$ 、多臓器 不全 11\%(4/38) と心筋炎 11\%(4/38) が続いてい ました。15 歳以上 65 歳未満では、肺炎が $46.2 \%$ (48/104) と主な死因であり、敗血症 5.8\%(6/104) と心筋炎 5.8\%(6/104) が続いていました。また、 65 歳以上の高齢者では、肺炎が 57\% (32/56) と死 因の半数以上であり、慢性呼吸器疾患や慢性腎不 全などの基礎疾患の増悪による死亡が 13\%(7/56)、 多臓器不全 9\%(5/56)が続いていました。

高齢者（65 歳以上）については、死亡例 56 例 のうち 53 例 (94.6\%) が基礎疾患を持っていました。 その基礎疾患の内訳を図 12 に示します。主な基 礎疾患は、慢性呼吸器疾患、慢性心疾患と糖尿病 がそれぞれ 36\% (20/53)、23\% (13/53)、21\%

(12/53)でした。

\section{年齢別の発生動向}

以下の分析では、推計受診者数を年齢階級別に 細分化したものを用いていますので、誤差が大き くなるものと考えられます。よって、これら情報 は、あくまで臨床における参考程度としてくださ い。

図 13 は、年齢階級別の推定受診率と人口 10 万人当たりの入院率を示しています。5-9歳、10-14 歳においては、8 割程度が何らかのインフルエン ザ様症状で、すでに医療機関を受診したと考えら
れます。

図 14 に推定受診者 100 人当たりの年齢階級別 入院率、重症化率及び死亡率を示します。これま での中・高齢者の受診数は確かに多くはありませ んが、発症した場合には季節性インフルエンザと 同様に高齢者は重症化する可能性が他の世代に比 して高いことが明らかです。これは、高齢者には 基礎疾患を有する方が多いことが背景にあるため と考えられます。

図 15 は、週別における年齢階級別推定受診者 数の推移を示しています。10月に入ってから、ま ず小児に急速に感染が拡がり、さらに約 1 力月遅 れて幼览、そして15歳以上へと流行したものと 考えられます。

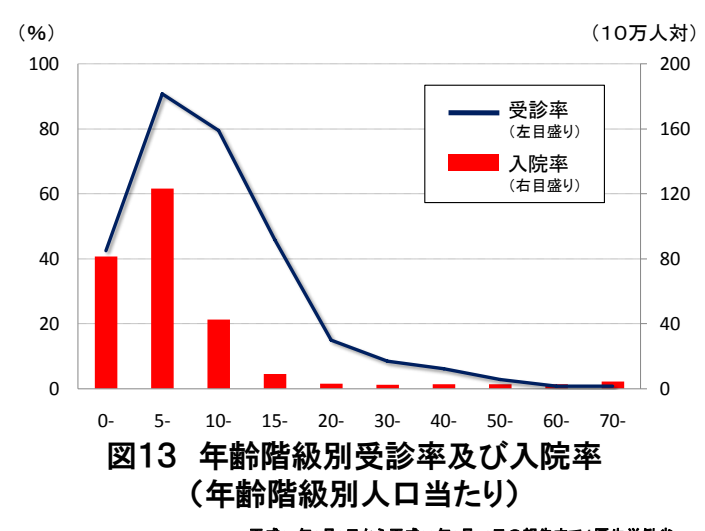

平成21年8月3日から平成22年3月16日の赤告まで/厚生労觔省

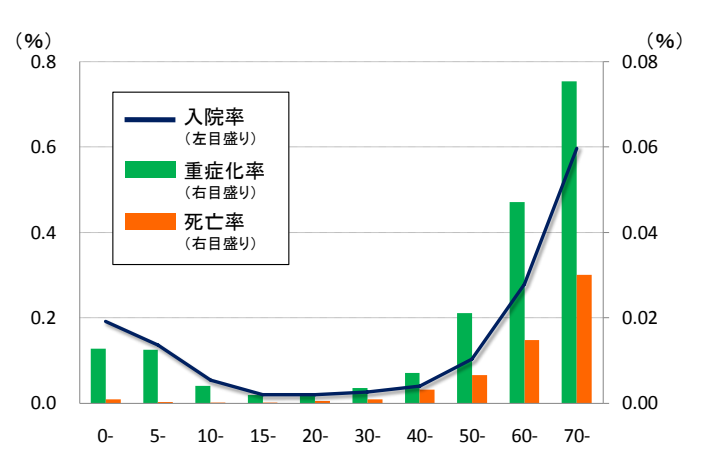

図14 年齢階級別入院率、重症化率及び死亡率 （推定受診者 100 人当たり） 


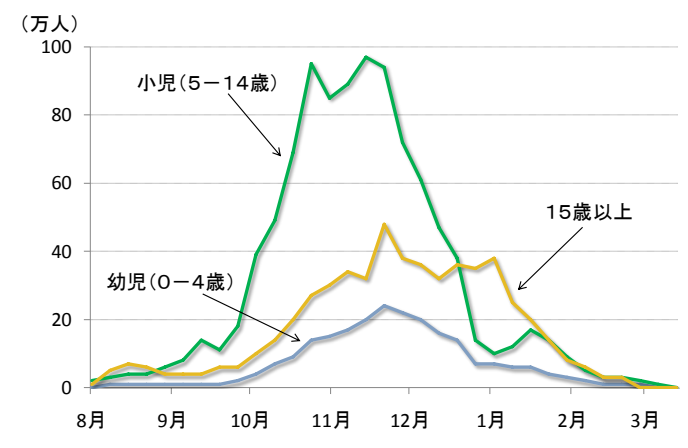

図15 年齡階級別推定受診者数の推移

今後、成人へと感染が拡がるのか、拡がるとす ればいつ頃になるのかを予測することは困難です。
しかし、新たな流行の波が発生する可能性はある ものと考え、今後の患者発生動向に注視しつつ、 とくに基礎疾患を有する方には当面は感染予防を 心がけるようご指導いただければと思います。ま た、医療機関には、基礎疾患を有する方が多く集 まっていることから、次の波に備えた院内感染防 止策について改めて徹底するようお願いいたしま す。

今後とも、各医療機関におかれましては、自治 体および厚生労働省が実施するサーベイランス へのご協力をよろしくお願いいたします。 